\title{
TESTICULAR SCHISTOSOMIASIS MIMICKING TUMOUR
}

\author{
NICOLA MORTATI NETO, JOÃO P. S. GRANDO, HORACIO A. MOREIRA
}

Professor Antonio Prudente Hospital, Cancer Institute, Londrina, Parana, Brazil

\begin{abstract}
Schistosomiasis or bilharziasis is a disease caused by Schistosoma. When infecting men the most common parasites are Schistosoma mansoni, Schistosoma japonicum and Schistosoma haematobium. The Schistosoma mansoni is the only endemic parasite in Brazil. We present a case of testicular schistosomiasis simulating malignancy. The case was treated successfully by excisional biopsy and praziquantel therapy. A review of the literature is discussed.
\end{abstract}

Key words: testis; nodule; Schistosoma mansoni Int Braz J Urol. 2004; 30: 502-3

\section{CASE REPORT}

A forty-year-old white man attended at the outpatient clinics of our hospital in May 2003, complaining about a nodule in his right testis. His wife recognized the nodule during a sexual intercourse. The physical examination revealed a painless $2-\mathrm{cm}$ solid nodule in his right testicle. The laboratory data including beta-human chorionic gonadotropin (betahCG), lactic dehydrogenase (LDH), and alpha-feto protein (AFP) were normal. The scrotal ultrasonography depicted a $1.8 \mathrm{~cm}$ hypoechoic nodule in the right testis. The patient was submitted to a frozen excisional biopsy. It revealed a granulomatous lesion with schistosomal egg (Figure-1). The patient was further treated with $40 \mathrm{mg} / \mathrm{kg}$ of praziquantel at single dose and after 10 months of follow-up, there is no evidence of the disease.

\section{COMMENTS}

Patients who present a testicular nodule or mass are always suspicious of harboring cancer since $80 \%$ of such lesions are germ cell carcinoma (1). Most patients are rendered nodule free by radical orchiectomy. This is because frozen biopsy is not so reliable in differentiating benign and malignant lesions.

Since 1995 we have performed 50 testicular explorations for solid nodules, 15 of them were submitted to an excisional frozen biopsy owing to the small size and normal markers. We have had 3 cases

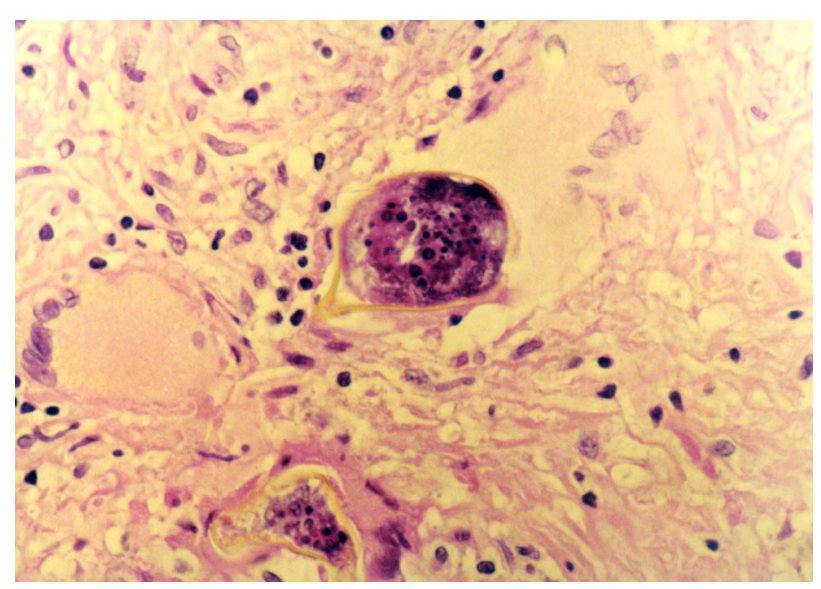

Figure 1 - Histology of the biopsy specimen, demonstrating the schistosomal egg (HE, X400). 
of testicular tuberculosis and 2 cases of testicular histiocitosis.

Urogenital schistosomiasis is a rare condition. It can affect kidney, ureter, bladder, prostate, epididymis and testis. Schistosoma mansoni is the main responsible for the disease in Brazil (2). The reason why schistosomal eggs are found in the testis has been a controversial issue. Portal hypertension seems to be an important condition to the development of ectopic lesions. The presence of collateral circulation would disseminate the eggs to other organs. The eggs can cause allergic reactions in the testicle, which mimic a testicular neoplasia (3). Testicular schistosomiasis can also cause intermittent pain owing to chronic manifestation of the disease (2).

We perform excisional frozen biopsy before radical orchiectomy in patients who have a small periphery nodule $(\leq 2 \mathrm{~cm})$ and normal serum markers, owing to the possibility of benign lesion. Unfortunately, there are no reliable imaging methods for differentiating a testicular lesion precisely and many benign cases are treated by radical orchiectomy when frozen biopsy is inconclusive.
There are few reports of testicular schistosomiasis described in the literature owing to the rarity of this entity in this organ. It usually mimics a malignant lesion presenting with a painless small solid nodule $(3,4,5)$. It should be part of differential diagnosis especially in endemic areas.

\section{REFERENCES}

1. Elert A, Olbert P, Hegele A, Barth P, Hofmann R, Heidenreich A: Accuracy of frozen section examination of testicular tumors of uncertain origin. Eur Urol. 2002; 41: 290-3.

2. Marese M, Nudel JE, da Costa JF: Schistosomiasis of the urogenital tract. Rev. Paul Med. 1982; 99: 45.

3. Franco Junior SC, Arruda HO: Schistosomiasis of the testis. Rev. Paul Med. 1981; 97: 139-40.

4. Wedel PG, Jess P: Testicular schistosomiasis simulating malignancy. Scand J Urol Nephrol. 1991; 25: 2378.

5. Lukacs T, Pajor L, Hamza L, el-Seaghy AA: Schistosomal granulation masquerating as testicular tumor. Acta Chir Hung. 1989; 30: 187-91.

Received: May 10, 2004

Accepted after revision: July 20, 2004

\author{
Correspondence address: \\ Dr Nicola Mortati Neto \\ Rua Bandeirantes 460, Centro \\ 86010-180, Londrina, Parana, Brazil \\ Phone: + 554333371800 \\ E-mail: nicolald@sercomtel.com.br
}

